\title{
(Re)conhecimento das condições de vida dos catadores autônomos de materiais reutilizáveis e recicláveis do Centro de Fortaleza
}

\author{
Survey of the life conditions of self-employed scavengers of \\ recyclable and reusable waste working in downtown Fortaleza
}

\author{
Ana Patrícia Pereira da \\ Silva \\ anapatricia_biologia@ \\ hotmail.com \\ Instituto Federal de \\ Educação, Ciência e \\ Tecnologia do Ceará - \\ IFCE (Campus Fortaleza) \\ Gemmelle Oliveira Santos \\ gemmelle@ifce.edu.br \\ IFCE (Campus Fortaleza)
}

\begin{abstract}
Resumo
Este trabalho apresenta parte dos resultados de uma pesquisa de mestrado cujo objetivo foi re(conhecer) as condições de vida (situação social, econômica e de trabalho) dos catadores autônomos que de materiais reutilizáveis e recicláveis que trabalham no Centro da cidade de Fortaleza-Ceará. O Centro foi escolhido porque sua dinâmica econômica e social resulta em uma grande quantidade de resíduos sólidos recicláveis diariamente, o que atrai muitos catadores. A pesquisa envolveu a aplicação de questionários com 25 catadores autônomos voluntários, sendo que cada questionário teve 20 perguntas entre abertas e fechadas. $\mathrm{O}$ trabalho de campo ocorreu durante o mês de março de 2016. Observou-se que a maioria dos entrevistados está na fase mais produtiva da vida, pertence ao sexo masculino, tem baixo nível de escolaridade, ganham abaixo de um salário mínimo e estão subordinados aos donos de depósitos. O cotidiano é marcado por desrespeito, problemas de saúde, precariedade dos instrumentos de trabalho e dificuldades na organização laboral. Curiosamente, quase todos se consideram satisfeitos com o trabalho e percebem a importância do seu trabalho para a limpeza da cidade, reciclagem e preservação ambiental.
\end{abstract}

Palavras-chave: Resíduos sólidos. Catadores de resíduos. Trabalho.

\begin{abstract}
This work presents part of a Master's degree research aimed to survey the life conditions (i.e. their social, economic and labor ones) of the self-employed recyclable and reusable waste scavengers working in downtown Fortaleza (State of Ceará, Brazil). The city's downtown was chosen because its economic and social life results in the production of a large quantity of recyclable solid waste on a daily basis, which in turn attracts many waste scavengers. This study involved 25 voluntary, selfemployed waste scavengers working in downtown Fortaleza who answered a questionnaire with 20 open and close questions. The field work was conducted in March 2016. Most of the participants were males in the most productive stage of their lives and with a low schooling level, earning less than a minimum wage and subordinated to the owners of the warehouses. Their daily life is characterized by disrespect, health problems, precarious working tools and labor organization difficulties. Curiously enough, almost all of them were satisfied with their job and were aware of the importance of their work for the cleaning of the city, recycling and environmental preservation.
\end{abstract}

Keywords: Solid waste. Waste scavengers. Work.

\section{Introdução}

Diversos fatores (globalização, crescimento urbano, industrialização, consumismo) têm aumentado significativamente o volume e a diversidade dos Resíduos Sólidos Urbanos (RSU).

No Brasil, segundo a Associação Brasileira de Empresas de Limpeza Pública e Resíduos Especiais - ABRELPE (2014) foram geradas aproximadamente 78,6 milhões de toneladas de RSU em 2014, sendo esse quantitativo 2,9\% a mais que o volume registrado em 2013. 
Uma importante estratégia para se minimizar os danos causados pelos RSU é a reciclagem, pois são conhecidos os seus benefícios tanto para sociedade como para o ambiente.

Segundo estudo realizado pelo Instituto de Pesquisa Econômica Aplicada - IPEA (2010), os atuais índices de reciclagem no Brasil geram por ano entre 1,4 e 3,3 bilhões de reais, mas poderiam gerar até 8 bilhões de reais por ano, com a ampliação e melhoria operacional dos sistemas existentes.

Os indivíduos que mais influem nos índices da reciclagem no Brasil são os catadores de resíduos sólidos, pois são responsáveis por coletar quase $90 \%$ de todo o material que é enviado às recicladoras brasileiras (Compromisso Empresarial para a Reciclagem - CEMPRE, 2011).

Segundo estimativa do IPEA (2012) existe aproximadamente 600 mil catadores no país e com a publicação da Lei Federal 12.305 (BRASIL, 2010), que trata da Política Nacional de Resíduos Sólidos, esse grupo de trabalhadores deverá assumir posição de destaque no contexto da sociedade e da gestão integrada dos RSU.

O serviço prestado pelos catadores de materiais reutilizáveis e recicláveis, profissão já reconhecida pela Classificação Brasileira de Ocupações do Ministério do Trabalho e Emprego, minimiza indiretamente a poluição do solo, água e ar, contribui com a limpeza da cidade, possibilita uma maior vida útil aos aterros sanitários e diretamente gera renda aos envolvidos na cadeia dos materiais.

No Nordeste Brasileiro, a quantidade de RSU gerada no ano de 2014 foi de 55.177 toneladas por dia - segunda região do país que mais produziu resíduos (ABRELPE, 2014) - e o número de catadores na região é de aproximadamente 116.528, o que representa 30\% do total estimado para o país (IPEA, 2013).

Dados do Conselho de Políticas Públicas e Gestão (CONPAM) mostram que Fortaleza-CE produz cerca de 5.876,69 toneladas de RSU por dia, sendo que outra parcela (ainda inestimada) é desviada do destino final (Aterro Sanitário de Caucaia) a partir do trabalho desenvolvido pelos catadores (associados ou autônomos).

Conforme a Secretaria do Meio Ambiente e Controle Urbano - SEMAM (2012) existem aproximadamente 20 (grupos, associações ou cooperativas) de catadores em Fortaleza, porém a grande maioria trabalha diretamente nas ruas, de forma autônoma, e em condição de subordinação aos donos de depósitos de materiais recicláveis e reutilizáveis.

Em Fortaleza (Ceará), a catação de materiais reutilizáveis e recicláveis acontece desde 1956 (SANTOS e RIGOTTO, 2008) e até a presente data pouco se conhece sobre esses sujeitos (quem são, como vivem, onde moram, quanto ganham, para quem trabalham, quais os seus sonhos e perspectivas), o que despertou o interesse em realizar esta pesquisa.

Os resultados da pesquisa podem orientar o município de Fortaleza-CE na criação de políticas públicas direcionadas a esse público-alvo. Além disso, esse trabalho pode ser um instrumento de educação ambiental e um guia para outros municípios cearenses. Indiretamente, o trabalho aproxima-se do cumprimento de diversos artigos da Política e do Plano Nacional de Resíduos Sólidos.

Este trabalho resume parte de uma pesquisa de mestrado pelo Programa de Pós-Graduação em Tecnologia e Gestão Ambiental do Instituto Federal de Educação, Ciência e Tecnologia do Ceará - IFCE (Campus Fortaleza). Seu objetivo é apresentar os resultados que re(conhecem) as condições de vida (situação social, econômica e de trabalho) dos catadores autônomos de materiais reutilizáveis e recicláveis que trabalham no Centro da cidade de Fortaleza-Ceará.

\section{Fundamentação teórica}

\subsection{Os catadores de materiais recicláveis e reutilizáveis}

\subsubsection{Breve história, lutas e conquistas no Brasil}

Conforme o IPEA (2013), os primeiros registros do trabalho desenvolvido por catadores de materiais recicláveis no cenário urbano brasileiro datam do Século XIX, principalmente em São Paulo e no Rio de Janeiro.

Segundo M. Gonçalves (2006) os primeiros esforços para agrupar ou mobilizar os catadores para um trabalho coletivo partiu de agentes da Igreja Católica por meio de programas de assistência social e ações beneficentes. Houve também, no final dos anos 80, iniciativas por parte do Partido dos Trabalhadores - PT (BENVINDO, 2010).

Em 1993, a Lei 8.666 (Artigo 24, XXVII) previu que é dispensável de licitação a contratação da coleta, processamento e comercialização de resíduos sólidos urbanos recicláveis ou reutilizáveis, em áreas com sistema de coleta seletiva de lixo, efetuados por associações ou cooperativas formadas exclusivamente por pessoas físicas de baixa renda reconhecidas 
pelo poder público como catadores de materiais recicláveis, com o uso de equipamentos compatíveis com as normas técnicas, ambientais e de saúde pública.

Em 1998, a criação do Fórum Lixo e Cidadania pelo Fundo das Nações Unidas para a Infância (UNICEF), fez crescer no Brasil o interesse em erradicar o trabalho infantil com o lixo e incluir de forma econômica e social os catadores (MINISTÉRIO DAS CIDADES, 2005).

Em meados de 1999 surge o Movimento Nacional dos Catadores de Materiais Recicláveis (MNCR), que busca a organização e a valorização da categoria por todo o Brasil.

O MNCR tem como objetivo garantir o protagonismo popular desses trabalhadores e por princípios: assegurar a independência de classe, incentivar à autogestão e organização, lutar pela gestão integrada dos resíduos sólidos, buscar tecnologias viáveis, apoio mútuo e solidariedade de classes, e lutar contra a privatização dos serviços públicos de saneamento básico.

Vários eventos também contribuíram para uma maior visibilidade dos catadores: em 2001, $1^{\circ}$ Congresso Nacional dos Catadores (Brasília-DF); em 2003, $1^{\circ}$ Congresso Latino-Americano de Catadores (Caxias do Sul-RS); em 2005, $2^{\circ}$ Congresso Latino-Americano de Catadores (São Leopoldo-RS); em 2008, $3^{\circ}$ Congresso Latino-Americano de Catadores (Bogotá, Colômbia); em 2009, $1^{\circ}$ Encontro Internacional de Catadores: a Expo Catadores (São Paulo-SP); em 2010, $4^{\circ}$ Congresso Latino-Americano de Catadores (Lima, Peru).

Outro evento de importância para os catadores foi a IV Conferência Nacional do Meio Ambiente cujo tema foi Resíduos Sólidos (MINISTÉRIO DO MEIO AMBIENTE, 2013).

A profissão dos catadores foi reconhecida pelo Ministério do Trabalho e Emprego em 2002 e a Classificação Brasileira de Ocupações a definiu como "aquele que cata, seleciona e vende material reciclável, e que se organiza de forma autônoma ou em cooperativa/associação com diretoria e gestão próprias".

No ano de 2003 foi criado o Comitê Interministerial da Inclusão Social dos Catadores, cujas principais finalidades são implementar o projeto Lixo e Cidadania, articular políticas e acompanhar a implementação dos programas voltados aos catadores, definir mecanismos de monitoramento e avaliação da implantação das ações integradas (MINISTÉRIO DAS CIDADES, 2005).

Em 2006, o Decreto 5.940 instituiu a separação dos resíduos recicláveis nos órgãos e entidades da administração pública federal direta e indireta, e previu sua destinação às associações e cooperativas dos catadores de materiais recicláveis. Conforme o Artigo $3^{\circ}$ estarão habilitadas a coletar os recicláveis as associações e cooperativas que atenderem aos seguintes requisitos:

I - estejam formal e exclusivamente constituídas por catadores de materiais recicláveis que tenham a catação como única fonte de renda; II - não possuam fins lucrativos; III - possuam infraestrutura para realizar a triagem e a classificação dos resíduos recicláveis descartados; e IV - apresentem o sistema de rateio entre os associados e cooperados.

Em 2007, o Governo Federal lançou o Programa CATAFORTE que teve por objetivo principal estruturar redes solidárias de empreendimentos de catadores de materiais recicláveis de modo a possibilitar avanços na cadeia de valor e inserção no mercado da reciclagem. Como objetivos específicos:

a) Fortalecer e ampliar os processos produtivos e gerenciais, por meio da estruturação de iniciativas de negócios sustentáveis coletivos e autogestionários, nivelando as condições operacionais e administrativas dos empreendimentos participantes das redes solidárias;

b) Realizar processos articulados de formação para a estruturação e gestão de negócios sustentáveis, com assessoramento técnico especializado, com foco na comercialização em rede de materiais recicláveis, prestação de serviços de coleta seletiva e de logística reversa e/ou a verticalização da produção;

c) Promover a inclusão de catadores informais, de rua e lixões, nos empreendimentos solidários e no acesso aos benefícios gerados pelas redes solidárias;

d) Promover a formalização e regularização de todos os empreendimentos participantes da rede solidária, adequando-os às exigências legais vigentes e às oportunidades da Política Nacional de Resíduos Sólidos; 
e) Promover a integração de diversas políticas públicas e outras iniciativas de apoio e inclusão de catadores de materiais recicláveis de modo a otimizar resultados, tal como articulação para desenvolvimento de ferramentas financeiras de crédito adequadas às redes de empreendimentos solidários.

O Plano Nacional sobre Mudanças do Clima (BRASIL, 2008), visando reduzir a pressão sobre os recursos naturais e promover a conservação de energia, estabeleceu como meta aumentar para $20 \%$ a reciclagem de resíduos sólidos no Brasil até o ano de 2015, com base nas experiências exitosas de Coleta Seletiva de alguns municípios brasileiros.

Em 2010, o Decreto 7.405 instituiu o Programa Pró-Catador com o objetivo de promover e integrar as seguintes ações voltadas aos catadores de materiais reutilizáveis e recicláveis:

I - capacitação, formação e assessoria técnica;

II - incubação de cooperativas e de empreendimentos sociais solidários que atuem na reciclagem;

III - pesquisas e estudos para subsidiar ações que envolvam a responsabilidade compartilhada pelo ciclo de vida dos produtos;

IV - aquisição de equipamentos, máquinas e veículos voltados para a coleta seletiva, reutilização, beneficiamento, tratamento e reciclagem pelas cooperativas e associações de catadores de materiais reutilizáveis e recicláveis;

V - implantação e adaptação de infraestrutura física de cooperativas e associações de catadores de materiais reutilizáveis e recicláveis;

VI - organização e apoio a redes de comercialização e cadeias produtivas integradas por cooperativas e associações de catadores de materiais reutilizáveis e recicláveis;

VII - fortalecimento da participação do catador de materiais reutilizáveis e recicláveis nas cadeias de reciclagem;

VIII - desenvolvimento de novas tecnologias voltadas à agregação de valor ao trabalho de coleta de materiais reutilizáveis e recicláveis;

IX - abertura e manutenção de linhas de crédito especiais para apoiar projetos voltados à institucionalização e fortalecimento de cooperativas e associações de catadores de materiais reutilizáveis e recicláveis.

Em 2010 foi publicada a Lei 12.305, que trata da Política Nacional de Resíduos Sólidos. O tema dos catadores é abordado diversas vezes:

Art. $7^{\circ}$ (XII): é objetivo da Política Nacional de Resíduos Sólidos a integração dos catadores de materiais reutilizáveis e recicláveis nas ações que envolvam a responsabilidade compartilhada pelo ciclo de vida dos produtos.

Art. $8^{\circ}$ (IV): é instrumento da Política Nacional de Resíduos Sólidos o incentivo à criação e ao desenvolvimento de cooperativas ou de outras formas de associação de catadores [...].

Art. 15 (V): a União elaborará, sob a coordenação do Ministério do Meio Ambiente, o Plano Nacional de Resíduos Sólidos, com metas para a eliminação e recuperação de lixões, associadas à inclusão social e à emancipação econômica de catadores [...].

Art. 18 ( $\left.\S 1^{\circ} \mathrm{II}\right)$ : serão priorizados no acesso aos recursos da União os Municípios que: implantarem a coleta seletiva com a participação de cooperativas ou outras formas de associação de catadores [...].

Art. 19 (XI): o plano municipal de gestão integrada de resíduos sólidos deve ter programas e ações para a participação dos grupos interessados, em especial das cooperativas ou outras formas de associação de catadores [...].

Art. 42 (III): o poder público poderá instituir medidas indutoras e linhas de financiamento para a implantação de infraestrutura física e aquisição de equipamentos para cooperativas ou outras formas de associação de catadores [...].

Em 2010, a Lei 12.309 (Lei de Diretrizes Orçamentárias) previu (Art. 36, VII) a transferência de recursos a título de auxílios para entidades privadas sem fins lucrativos e desde que sejam voltadas diretamente às atividades de coleta $\mathrm{e}$ processamento de material reciclável, desde que constituídas sob a forma de associações ou cooperativas integradas por pessoas em situação de risco social [...].

A Instrução Normativa $\mathrm{n}^{\circ}$ 01/2010 dispõe sobre os critérios de sustentabilidade ambiental na aquisição de bens, contratação de serviços ou obras pela Administração Pública Federal direta, autárquica e fundacional. O Art. $6^{\circ}$ (VI) 
prevê que as empresas contratadas deverão adotar práticas de sustentabilidade quanto à separação dos resíduos recicláveis descartados pelos órgãos em que prestam seus serviços e destiná-los às associações e cooperativas dos catadores de materiais recicláveis.

Em 2012 foi publicado o Plano Nacional de Resíduos Sólidos. Nele foram apontadas as seguintes estratégias em relação aos catadores:

Promover o fortalecimento das cooperativas e associações de catadores, buscando elevá-las ao nível mais alto de eficiência.

Promover a criação de novas cooperativas e associações e regularização daquelas já existentes, com vistas a reforçar os vínculos de trabalho, incluir socialmente e formalizar os catadores que atuam de forma isolada.

Promover a articulação em rede das cooperativas e associações de catadores.

Criar mecanismos de identificação e certificação de cooperativas, para que não haja falsas cooperativas de catadores beneficiadas com recursos públicos.

Fortalecer iniciativas de integração e articulação de políticas e ações federais direcionadas para o catador, tais como o programa pró-catador e a proposta de pagamentos por serviços ambientais urbanos.

Estipular metas para a inclusão social de catadores e garantir que as políticas públicas forneçam alternativas de emprego e renda aos catadores que não puderem exercer sua atividade após a extinção dos lixões, prevista para 2014.

Estipular metas com o objetivo de inclusão social e garantia de emprego digno para até 600 mil catadores, até o ano de 2014.

As metas focadas na garantia de emprego devem estabelecer o piso de um salário mínimo para a remuneração do catador. $\mathrm{O}$ piso de remuneração também deve levar em conta as diretrizes do Plano Brasil sem miséria, que prevê renda per capita mínima de 70 reais por membro da família.

Estimular a participação de catadores nas ações de educação ambiental e sensibilização porta-a-porta para a separação de resíduos na fonte geradora, mediante a sua adequada capacitação e remuneração.

Demandar dos municípios a atualização de sistemas de informação sobre a situação dos resíduos municipais e gestão compartilhada dos resíduos.

Estabelecer metas e critérios para que os municípios incluam os catadores na gestão municipal de resíduos sólidos.

Garantir o acesso dos catadores aos resíduos sólidos urbanos coletados seletivamente.

Promover a integração dos catadores de materiais recicláveis aos sistemas de logística reversa.

\subsubsection{Importância social, econômica e ambiental da atividade}

Para o Ministério do Meio Ambiente - MMA a atuação dos catadores contribui para coleta de resíduos sólidos urbanos, retira grande parte dos resíduos das ruas, aumenta a vida útil dos aterros sanitários e diminui a demanda por recursos naturais.

A catação de materiais recicláveis agrega diferentes aspectos: geração de renda, proteção dos recursos naturais, educação ambiental e inclusão social (TAVARES, 2009).

Para Galon (2015), a atividade do catador subsidia a sociedade, o meio ambiente e o mercado da reciclagem.

Conforme Magalhães (2012) os catadores realizam um serviço de utilidade pública, pois a reinserção de materiais no ciclo produtivo gera benefícios positivos para a natureza e para a sociedade. Essa reintrodução colabora para reduzir o uso da água e de energia (ROLIM, TEIXEIRA e FERNANDES, 2015).

Na visão de Gonçalves et al. (2013) os catadores são considerados importantes prestadores de serviços ambientais, na medida em que diminuem a quantidade de resíduos sólidos e seus impactos nas cidades brasileiras. Eles prestam um serviço público que favorece a limpeza da cidade e contribui significativamente para a preservação do meio ambiente urbano (IZAIAS, 2010). 
Para o IBAM (2001), as prefeituras economizam recursos no serviço de coleta de lixo convencional a partir do trabalho desenvolvido por esses trabalhadores.

Os catadores são verdadeiros agentes ambientais e sua atividade é responsável pelos altos índices de reciclagem de alguns materiais, como as latas de alumínio (que permitiram colocar o Brasil no ano de 2012 na liderança mundial do segmento) - ABRELPE (2014).

Os catadores interferem de maneira fundamental no ciclo de limpeza e de vida dos produtos, além disso, participam diretamente do gerenciamento integrado dos resíduos (PINHEL, ZANNIN e DEL MÔNACO, 2011).

As pesquisas de Santos (2008) e Araújo (2009) mostram, por exemplo, que os próprios catadores sabem reconhecer os múltiplos benefícios de suas atividades.

No Estado do Ceará (Lei 12.225/93) são consideradas como atividades ecológicas de relevância social e de interesse público, a coleta seletiva e a reciclagem do lixo (CEARÁ, 1993).

Couto (2012), afirma que o trabalho desenvolvido pelos catadores traz ganhos positivos em três diferentes direções: i) organização de um novo movimento social que propõe um modelo de inclusão social e de sustentabilidade; ii) em âmbito econômico e de inclusão social; iii) em âmbito subjetivo, melhora da autoestima, na (re)conquista de sua cidadania.

Para Gonçalves (2005) os catadores são colaboradores tanto ambientais quanto econômicos, por isso, é fundamental que tenham políticas públicas que auxiliem e garanta seus direitos.

São os catadores que diariamente evitam que milhões de toneladas de materiais sejam enviados para lixões e aterros sanitários, e são eles quem sustentam o rico mercado da reciclagem (GONÇALVES, 2005), por isso as políticas públicas deveriam valorizar esses sujeitos da mesma forma que tentam valorizam a indústria da reciclagem.

\subsubsection{Aspectos da vida e do trabalho}

Conforme Ribeiro, Nardi e Machado (2012) as pessoas se envolvem no trabalho de catação de materiais por vários motivos: para suprir vícios com o álcool e outras drogas, para complementar a renda ou porque só encontraram essa maneira para sobreviver.

O trabalho desenvolvido pelos catadores permite a exposição desses sujeitos a agentes físicos (ruído, poeira, calor e frio), agentes químicos (embalagens contaminadas por substâncias tóxicas sólidas, líquidas ou gasosas) e agentes biológicos (bactérias, fungos, vírus e parasitas) - MINISTÉRIO DA SAÚDE (2002).

Segundo Cavalcante e Franco (2007), essa exposição pode acontecer de modo de direto, quando há um contato imediato dos trabalhadores com os agentes patogênicos presentes nos resíduos, e de modo indireto, por meio da amplificação de algum fator de risco, que age de forma descontrolada sobre o entorno e por três vias principais: a ocupacional, a ambiental e a alimentar.

De acordo com Hoefel et al. (2013) os catadores sabem da periculosidade do ambiente de trabalho e, a maioria, já sofreu algum tipo de acidente. Após um dia de trabalho, os catadores relatam dores musculares, na coluna, cefaleia, resfriados e um extremo cansaço devido à exposição ao sol e esforços físicos (L. DOBRACHINSKI; DOBRACHINSKI, 2016).

A Norma Regulamentadora $n^{\circ} 15$, do Ministério do Trabalho e Emprego, considera a atividade do catador como insalubre em grau máximo.

Os catadores representam um grupo que precisa ser atendido pela Política Nacional de Saúde do Trabalhador, já que a mesma contempla pessoas e grupos em situação de maior vulnerabilidade, em atividades de maior risco para a saúde e submetidas a formas nocivas de discriminação (MINISTÉRIO DA SAÚDE, 2012).

Entende-se do estudo realizado por Gonçalves et al. (2013) que não só os catadores de rua estão expostos a doenças relacionadas ao trabalho, mas principalmente os catadores dos lixões.

Conforme Rancura (2005) para realizar seu trabalho os catadores utilizam sacolas, bicicletas, carrinho de tração humana - geralmente feitos com carcaça de geladeira - e carroças com animais.

Os catadores passam por diversas adversidades, acidentes e riscos na sua atividade, além de não serem remunerados de forma adequada pelos serviços ambientais que realizam e sofrem com a instabilidade do mercado de reciclagem (IPEA, 2010).

Segundo Galon (2015), os catadores de materiais sofrem diversas formas de adoecimento ou desgaste de saúde e apesar de terem conhecimento sobre os aspectos que causam seu adoecimento, sua prioridade é a busca pela sobrevivência. 
Conclusão semelhante foi feita por Silva, Lubarino e Souza (2010) quando afirmaram que, para o catador, a baixa remuneração preocupa mais que os problemas de saúde adquiridos durante as coletas e mais que as violências sofridas.

O aspecto econômico é apenas um dos problemas enfrentados pelos catadores; eles vivenciam muitas problemáticas sociais relacionadas com conflitos familiares, condições precárias de trabalho, altos índices de violência, baixa autoestima, além do baixíssimo nível de escolaridade (FEITOSA, 2011).

Conforme Bosi (2008), Galdino e Malysz (2012), Moraes (2009), Silva e Joia (2008), Rios (2008), a baixa escolaridade dos catadores influencia na exclusão e na (re)ingressão no mercado de trabalho.

Pesquisa realizada por Rolim, Teixeira e Fernandes (2015) revela que o baixo nível de escolaridade contribui para que os mesmos sejam impossibilitados a concorrer as vagas no competitivo e disputado mercado de trabalho formal.

Segundo pesquisa do IPEA (2013), a porcentagem de catadores analfabetos é de 20,5\%. Isso representa um grave problema social, pois limita as oportunidades profissionais e leva a exclusão social, além de afetar a qualidade de vida do indivíduo e de sua família.

A atividade de catação gera renda para diversas famílias, apesar da precarização sofrida pelos catadores. Uma alternativa para melhoria de renda, condições de trabalho e qualidade de vida seria organização dos trabalhadores em associação ou cooperativas (TROMBETA, 2012).

Dados do IPEA (2013) revelam que nos últimos anos a renda média alcançada pelos catadores supera o patamar do salário mínimo em quase todas as regiões, com exceção do Nordeste.

\section{Metodologia}

\subsection{Descrição da área estudada}

O trabalho foi realizado na cidade de Fortaleza (Ceará) que, conforme o Instituto de Pesquisa e Estratégia Econômica do Ceará - IPECE (2015), tem 313,14 km², 2.452.185 habitantes e densidade demográfica 7.786,52 (hab./ $\mathrm{km}^{2}$ ). Atualmente, a cidade é subdivida em 07 Secretarias Executivas Regionais - SER (subprefeituras), o que permite descentralizar as decisões do poder público municipal.

Segundo dados do Atlas do Desenvolvimento Humano no Brasil (2013), Fortaleza-CE tem Índice de Desenvolvimento Humano - IDH igual a 0,754, mas cada Secretaria Executiva Regional tem suas particularidades (número de bairros e de habitantes, condições sociais, econômicas, sanitárias, ambientais etc).

O bairro Centro, durante muitos anos, pertenceu a Secretaria Executiva Regional 2, mas sua natureza (predominantemente comercial e de serviços) resultou na criação de uma Secretaria específica: a SERCEFOR (Secretaria Regional do Centro).

De acordo com o Censo do Instituto Brasileiro de Geografia e Estatística - IBGE (2010), a SERCEFOR é composta por 28.538 habitantes, tem $4,85 \mathrm{~km}^{2}$ e cerca de 12.078 domicílios. Conforme a Secretaria de Desenvolvimento Econômico (SDE) da Prefeitura Municipal de Fortaleza (PMF), a Regional abriga 20\% dos empregos formais do município.

Em função da dinâmica econômica e social do Centro da cidade, uma grande quantidade de resíduos sólidos recicláveis é gerada diariamente. Uma pesquisa feita com os resíduos do bairro aponta para a presença de 51,9\% (em média) de materiais recicláveis. Essa característica atrai muitos catadores, por isso o trabalho de campo foi realizado no referido bairro.

\subsection{Etapas da pesquisa}

A primeira etapa envolveu a busca e leitura de arquivos virtuais e impressos sobre o tema principal da pesquisa: catadores de materiais reutilizáveis e recicláveis. O material consultado (artigos, monografias, dissertações, teses, leis, decretos, normas, manuais etc) permitiu construir um breve retrato da história dos catadores, organizar cronologicamente as lutas e avanços da categoria, discorrer sobre a múltipla importância do segmento e sobre suas condições de vida, trabalho e saúde.

A segunda etapa envolveu a elaboração de um questionário para realização de um pré-teste. Sua aplicação ocorreu com o apoio dos estudantes do $3^{\circ}$ semestre da Graduação em Tecnologia e Gestão Ambiental do Instituto Federal de Educação, Ciência e Tecnologia - IFCE (Campus Fortaleza). Os catadores entrevistados (total: 61) foram aleatoriamente 
encontrados em diversos bairros da cidade pelos estudantes. Os resultados do trabalho foram discutidos em sala de aula e permitiram aprimorar o questionário definitivo.

A terceira etapa envolveu a aplicação, exclusivamente pela estudante do mestrado, do questionário definitivo. Foram entrevistados 25 catadores autônomos voluntários encontrados no Centro da cidade de Fortaleza. Cada questionário tinha 20 perguntas entre abertas e fechadas. O trabalho de campo ocorreu durante o mês de fevereiro e março de 2016. Essas perguntam buscaram re(conhecer) suas condições econômicas, sociais e de trabalho.

A maior parte das pesquisas sobre o assunto em Fortaleza-CE tomou como objeto de estudo catadores associados e/ ou cooperados. Como pouco se sabe sobre os catadores autônomos, que são maioria na cidade, é que se decidiu trabalhar com esse grupo.

\subsection{Classificação da pesquisa}

Quanto à natureza, essa pesquisa se classificou como aplicada. Quanto aos objetivos, foi exploratória. Quanto aos procedimentos técnicos, um levantamento. Quanto aos meios de investigação, um estudo de campo. Quanto à abordagem, quantitativa. Quanto ao método, indutivo.

\section{Resultados e Discussão}

Entre os 25 catadores entrevistados, $48 \%$ tem até 39 anos, 28\% tem entre 40 e 60 anos e $24 \%$ tem acima de 60 anos. Essa distribuição etária mostra que a grande maioria dos entrevistados está na fase mais produtiva da vida e que os mais jovens nunca estiveram inseridos no mercado de trabalho formal e/ou tem a catação como primeira experiência de trabalho.

$\mathrm{Na}$ literatura são encontradas várias referências com relação à faixa etária dos catadores (Bosi, 2008; Medeiros e Macedo, 2006; Severo, 2008; Silva e Jóia, 2008; Silva e Santos, 2015), sendo recorrente a discussão sobre os motivos que os levaram a exercer essa atividade, especialmente a baixa escolaridade e a situação de desemprego.

Conforme Feitosa (2011) o trabalho dos catadores surge no contexto de poucas oportunidades de trabalho, desqualificação profissional, precariedade de vida, pobreza e mudanças no mercado.

Nesta pesquisa, o entrevistado mais jovem tinha 21 anos de idade e nunca teve outra profissão. Segundo ele, a falta de documentos pessoais (RG, $\mathrm{CPF}$ ) foi o motivo que o levou a trabalhar no ramo. Além dele, um irmão também trabalha com "reciclagem".

A entrevistada mais velha foi uma senhora de 71 anos. Ela já trabalhou como operária em uma fábrica de costura, mas está na "reciclagem" há 15 anos. Durante esse período afirmou nunca ter contraído doenças. Se sente satisfeita com o trabalho, mas percebe que as pessoas se incomodam com a "carroça".

Entre os homens, o mais velho tem 63 anos e anteriormente trabalhou como bombeiro hidráulico. Após ficar desempregado não conseguiu arranjar outro emprego por conta da idade avançada. Tem dificuldade de carregar o carrinho e visão comprometida.

Para Oliveira, A. et al. (2011), o trabalho do catador - por exigir intenso esforço físico - se torna difícil até para os mais jovens, quanto mais para aqueles com idade avançada (idosos).

Conforme Kirchner, Saidelles e Stumm (2009) a idade avançada pode excluir as pessoas do mercado de trabalho formal, mas a catação não exige idade nem seleção, porém é inegável que o serviço exige esforços físicos inapropriados para os mais velhos, já que os carinhos exigem bastante esforço e certa habilidade diante do tráfego.

Com relação à distribuição dos entrevistados por sexo, observou-se que 22 (88\%) pertencem ao sexo masculino e 03 (12\%) ao feminino. A distribuição observada concorda com a literatura: Filard, Siqueira e Binotto (2011), Frota (2014), Galon (2015), IPEA (2013) e Rancura (2005).

Para Galon (2015), IPEA (2013) e Rancura (2005) a presença masculina é predominante no trabalho informal de catação de materiais porque as mulheres catadoras possuem outras atribuições, como cuidar do lar e da família.

No trabalho de Filard, Siqueira e Binotto (2011) foram elencados outros motivos: a catação nas ruas exige grande esforço físico e resistência por isso é desempenhada mais por homens que por mulheres. A questão do vigor físico também foi destacada por Bolfe et al. (2014), Kirchner, Saidelles e Stumm (2009) e Oliveira, A. et al. (2011). 
Outro fato que corrobora com a majoritária presença masculina nas ruas é que as mulheres catadoras preferem trabalhar nas cooperativas e/ou associações, pois aceitam melhor as regras do trabalho em grupo diferentemente dos homens (FROTA, 2014).

Com relação à distribuição dos entrevistados por estado civil, observou-se que 13 (52\%) são solteiros, 04 (16\%) possuem união estável (junto), 03 (12\%) são divorciados, 02 (8\%) são viúvos e 4\% são casados (01), separado (01) e sem informação (01).

Na literatura (Abreu, 2011; Aquino et al., 2015; Frota, 2014; Rios, 2008; Sousa, 2009; Tavares, 2009; Tenório, 2007) existem muitas tentativas de se justificar o fato de a maioria dos catadores serem solteiros que vão da aparência à baixa renda.

Para alguns entrevistados, a baixa renda e o medo de assumir responsabilidades são os principais motivos para ficar solteiro. Conforme Bolfe et al. (2014), a renda dos catadores não atende às necessidades básicas de uma família, mas Kirchner, Saidelles e Stumm (2009) afirmam o contrário. Alguns catadores (12\%) afirmaram que toda a família está envolvida na atividade de catação (irmãos, pais, filhos etc).

No quesito escolaridade, observou-se que 19 (76\%) possuem o ensino fundamental incompleto, 03 (12\%) possuem o ensino fundamental completo, 02 (8\%) possuem o ensino médio incompleto e $01(4 \%)$ possuem o ensino médio completo.

A distribuição observada mostra que os catadores de materiais recicláveis possuem baixo nível de escolaridade. Essa realidade também foi encontrada por Bosi (2008), Brasil (2015), Frota (2014), Medeiros e Macêdo (2006), Pantano Filho e Rosa (2011) e Santos Filho, Rocha, Lima Filho (2012).

Na pesquisa de Pantano Filho e Rosa (2011), 75\% dos entrevistados não completaram o ensino fundamental, e no trabalho de Bosi (2008), alguns catadores sequer tinham frequentado a escola.

A formação escolar insuficiente é um obstáculo na busca por outra opção de trabalho e para alguns, motivo de vergonha e humilhação (MEDEIROS e MACÊDO, 2006).

A baixa escolaridade é um dos motivos para que essas pessoas se envolvam na catação de recicláveis, já que o mercado de trabalho está cada vez mais exigente (SANTOS FILHO, ROCHA e LIMA FILHO, 2012).

Para Frota (2014) o nível de escolaridade dos catadores prejudica sua capacidade em conhecer e acompanhar seus direitos e deveres, além de facilitar que sejam lesados financeiramente.

Os baixos índices de escolaridade são fundamentados por suas dificuldades ao acesso escolar, pois suas condições econômicas exigem sua inserção precoce no mercado de trabalho informal para garantir o sustento familiar, afirma (BRASIL, 2015).

Com relação à estrutura familiar, observou-se que $17(68 \%)$ possuem filhos e 08 (32\%) não possuem. Alguns catadores relataram que seus filhos também exercem essa atividade, sendo comum o interesse que os filhos consigam outro futuro. Alguns têm estimulado os filhos a continuar nos estudos e/ou a conseguir outro tipo de trabalho; mesmo resultado obtido por Gonçalves (2004).

A pesquisa feita pelo IBGE (2010) revela que alguns fatores podem interferir na taxa de fecundidade entre os catadores como, a cor, o grau de instrução e o rendimento. As mulheres pardas e negras, por exemplo, apresentam indicadores semelhantes, enquanto as brancas possuem menor número de filhos.

Dos entrevistados, 10 afirmaram ter quatro filhos ou mais, indicando total ausência de controle de natalidade, concordando com Rios (2008). Os 13 catadores que se consideraram solteiros na pesquisa, 5 possuem filhos, corroborando com o estudo de Rocha (2015), cujos catadores, independente do seu estado civil, tinham filhos.

Com relação às atuais formas de ocupação, observou-se que a grande maioria (64\%) exerce exclusivamente a função de catador, mas existem aqueles que exercem atividades paralelas para conseguir renda extra (carpinteiro, soldador, flanelinha). Esses dados são ratificados pelos trabalhos de Santos Filho, Rocha e Lima Filho (2012), Tavares (2009) e Waldman et al. (2014).

Em uma pesquisa feita com os catadores do município de Goioerê (Paraná), Carvalho (2011) observou que 33\% obtinham renda apenas da coleta de materiais. Já a pesquisa de Rios (2008) aponta que os catadores têm a catação como principal atividade de ocupação, mas alguns complementam a renda com atividades esporádicas.

Para Vieira (2011) os catadores não têm escolha; a catação lhes é imposta, pois desde criança acompanham seus pais nessa atividade. 
No estudo de Moreira (2013) - realizado com os catadores do bairro São José (Fortaleza-CE) - verificou-se que estes trabalhadores não tiveram a oportunidade de escolher entre a catação e o trabalho formal; a necessidade socioeconômica se impôs.

Conforme pesquisa realizada no bairro Granja Portugal (Fortaleza-CE) os adultos fazem as crianças entenderam que trabalhar é melhor que ir para a marginalidade, porém essa ideia supre as necessidades adultas e não necessariamente as das crianças, desumanizando-as (GONÇALVES, R., 2006).

Os catadores levam seus filhos para o local de trabalho (lixão, rua, associação e/ou cooperativa) porque não tem com quem deixá-los ou o acesso à escola é restrito, consequentemente isso influencia que os filhos exerçam a mesma profissão dos pais (DIAS, 2002; MAGALHÃES, 2012).

Entre os entrevistados, $12(48 \%)$ trabalham na atividade de "reciclagem" há quase 10 anos e 09 (36\%) há mais de 10 anos. Esses resultados permitem entender que a catação não gera renda suficiente para que o sujeito mude de vida e se ocupe em outra atividade. Três catadores (12\%) estão na catação há poucos meses, pois perderam o emprego recentemente. Os demais não sabem informar há quanto tempo trabalham no ramo.

Uma das três mulheres entrevistadas afirmou ser pioneira na catação de materiais pelas ruas do Centro de FortalezaCE. A senhora, que tem 71 anos de idade, mora no bairro Nossa Senhora das Graças, é viúva, teve 9 filhos e ganha até $\mathrm{R} \$ 250,00$ por mês.

Com relação às formas de ocupação anteriores ao serviço de catação, apenas $16 \%$ dos entrevistados não tiveram outras experiências profissionais anteriormente, demonstrando um cenário de total desemprego estrutural.

As catadoras entrevistadas afirmaram já ter trabalhado como cozinheira e operária de fábrica. No estudo de Soares (2014), as catadoras também exerceram outras atividades como babá, doméstica, cozinheira e costureira. Bastos e Araújo (2015) e Rios (2008) verificaram diversas atividades desenvolvidas pelos catadores antes de sua inserção na "reciclagem" e os motivos que os levaram a essa atividade foram o desemprego, a necessidade e a falta de opção.

Nesta pesquisa, cada entrevistado narrou seus motivos para realizar a atividade de catador: preciso ganhar dinheiro, não gosto de ficar parado, estou desempregado, preciso sustentar o vício, a família, não quero roubar, estou complementando a renda, gosto de ser autônomo, não tenho documentos pessoais, tenho idade avançada etc.

Conforme Castilhos Junior et al. (2013) e M. Oliveira et al. (2011), a principal razão para trabalhar com os materiais recicláveis é o desemprego, posteriormente a baixa escolaridade, limitações físicas e a idade avançada.

Segundo Severo (2008) a dificuldade de recolocação no mercado de trabalho é o motivo para tantos homens como mulheres realizarem a catação.

Com relação ao número de horas habitualmente trabalhadas, a minoria (8\%) trabalha um turno (4 horas/dia), 20\% trabalham dois turnos ( 8 horas/dia), 24\% trabalham três turnos (12 horas/dia), 16\% trabalham quatro turnos (16 horas/ dia), 24\% trabalham acima de 16 horas/dia e $8 \%$ não soube informar.

Essa diversidade de horários é consequência da liberdade que o catador autônomo afirma ter para determinar o seu próprio ritmo de trabalho. Alguns trabalham mais horas para conseguir maior renda.

De acordo com Castilhos Junior et al. (2013) e Santos (2013) alguns fatores podem justificar as diferenças de renda entre os catadores: nível de instrução escolar, quantidade de horas trabalhadas, quantidade, qualidade e preço do material que é coletado, ritmo de trabalho, crise financeira, etc.

No geral, a distribuição observada mostra que a carga horária dos catadores é superior a de outros trabalhadores e que alguns trabalham dia e noite, sob chuva e sol. Esse fato pode ser justificado pela necessidade de recolher uma maior quantidade de recicláveis para obter um melhor rendimento como afirma Abreu (2011).

Dos entrevistados 24\% afirmaram trabalhar mais de $16 \mathrm{~h} /$ dia, muitas vezes ininterruptas, mesmo sendo um trabalho extenuante e que exige muita força física. Conforme Magera (2003) os catadores carregam mais de 200 quilos de lixo por dia e podem chegar a percorrem vinte quilômetros por dia.

Na pesquisa de Rabelo, Silva e Carneiro (2006) a maioria dos catadores pertencentes ao Centro de Fortaleza-CE trabalha no período diurno, porém alguns também trabalham a noite e tem o hábito de dormir no seu local de trabalho (nas ruas).

Conforme o IPEA (2013) existe uma dinâmica na rotina diária do trabalho dos catadores; alguns seguem uma árdua jornada de trabalho, outros trabalham determinadas horas por dia ou mesmo intercalam os dias. 
No estudo de Pereira (2010) uma catadora relata que o término do trabalho é determinado pela resposta corporal, ou seja, as dores e o cansaço é que ditam a hora de parar.

Para sobreviver os catadores enfrentam uma longa e exaustiva jornada de trabalho, com mais de oitos horas diárias e muitas vezes não tem descanso nem nos fins de semana (ALMEIDA; FIGUEIREDO; BARBOSA, 2014; OLIVEIRA, M. et al., 2011).

Alguns catadores escolhem trabalhar no final do dia, pois há grande quantidade de materiais deixados por comerciantes e residências, e evita a exposição solar (RIBEIRO, 2009).

Com relação à renda média mensal, observou-se que $15(60 \%)$ dos entrevistados ganham abaixo de um salário mínimo, 07 (28\%) ganham entre um e dois salários, 02 (8\%) ganham acima de dois salários e 01 (4\%) não soube informar. Além da baixa remuneração, $60 \%$ dos entrevistados sustentam pelo menos um dependente e nenhum catador afirmou receber benefícios do governo.

Os dados obtidos condizem com outros estudos: Carvalho (2011), Castilhos Júnior et al. (2013), Cavalcante, Alencar e Barbosa (2014), Oliveira (2011), Santos (2013).

Em uma pesquisa feita com os catadores do município de Goioerê (Paraná), Carvalho (2011) encontrou renda abaixo de um salário mínimo, e $47 \%$ dos entrevistados como os únicos responsáveis pela renda familiar.

Galdino e Malysz (2012) revelam que a venda de materiais não é suficiente para garantir as condições mínimas e dignas de sobrevivência dos catadores.

Conforme Oliveira (2011) os catadores se sentem insatisfeitos com a renda que conseguem, mas é com ela que mantém suas necessidades básicas.

Nesta pesquisa, de uma forma geral, constatou-se que a renda das mulheres é menor que a renda dos homens. Um bom exemplo é que os que responderam ganhar acima de dois salários mínimos são do sexo masculino. Um deles tem 62 anos, é divorciado, tem 3 filhos e mora no Centro. O outro catador afirmou ser morador de rua, separado, 46 anos, 3 filhos e com ensino médio completo.

Os cinco materiais mais encontrados pelos catadores no Centro da cidade são o papelão, plástico, papel, alumínio e vidro. O item de maior valor de venda é o alumínio (em média $\mathrm{R} \$ 1,97 / \mathrm{Kg}$ ) e o de menor valor é o papelão (em média R\$ $0,11 / \mathrm{Kg}$ ), sendo que o alumínio é um produto "raro" e o papelão tem em excesso, invertendo os ganhos no final.

Todos os catadores vendem os materiais para depósitos/sucatas que existem no próprio Centro da cidade. Essa venda ocorre por dois motivos principais: os catadores precisam suprir suas necessidades diárias e não possuem local para armazenar materiais.

Bortoli (2009) afirma que a venda individual e a pouca quantidade de resíduos são fatores que mantem baixo o nível de renda entre os catadores.

Cavalcante, Alencar e Barbosa (2014) lembram que a baixa renda mensal também é consequência do fato dos catadores venderem os materiais coletados para intermediários (deposeiros, sucateiros, atravessadores) e não diretamente para a indústria.

A relação entre o dono do depósito e o catador merece discussão, pois alguns carrinhos de coleta (geralmente feitos com carcaça de geladeira) são emprestados pelo dono do depósito para o catador exercer sua atividade. Ao retornar da jornada de trabalho, o catador está praticamente obrigado a vender o que recolheu para essas pessoas. Essa relação aumenta a dependência do catador em relação ao dono de depósito e reduz seus lucros.

Conforme Gonçalves et al. (2013), os catadores trabalham indiretamente para atravessadores e indústrias, não tem seu trabalho valorizado, sendo muitas vezes explorados e lesados por quem compra seus resíduos.

A maior parte dos catadores entrevistados nesta pesquisa reside em outros bairros e se deslocam até o Centro da cidade apenas para exercer suas atividades (56\%). Alguns moram na periferia de Fortaleza-CE e até em municípios da Região Metropolitana, como Maracanaú. Em função da distância, dormem pelas ruas e praças do Centro, e se alimentam a partir de doações de lanchonetes e restaurantes.

Na visão de $64 \%$ dos entrevistados, o maior problema enfrentado no cotidiano é o desrespeito. Miura e Sawaia (2013) constataram que os sentimentos de vergonha, preconceito e discriminação estão presentes na profissão dos catadores. Resultados parecidos aos de Teixeira, M. (2010). 
Os catadores sofrem preconceito da sociedade e também de familiares; muitas vezes por parte de seus filhos, pois estes se sentem inferiorizados pela atividade de seus pais (ROLIM; TEIXEIRA; FERNANDES, 2015). Segundo Severo (2008) os catadores que já tiveram um emprego formal se sentem constrangidos em desenvolver essa atividade.

Do total entrevistado, 56\% afirmou não ter nenhuma doença diagnosticada pelo serviço formal de saúde, mas percebem que seu trabalho traz danos à saúde, especialmente problemas de pele, infecções, doenças respiratórias, tétano e dores no corpo.

De acordo com Gonçalves (2004) o contato direto com o lixo permite exposição a agentes patogênicos através da inalação, contato dérmico e via oral (principalmente alimentos), além de existirem outros riscos (cortes, atropelamentos).

Na pesquisa realizada por Porto et al. (2004), os catadores relataram problemas respiratórios, de pele e de coluna, alergias, pneumonias, dores de cabeça, estômago, hanseníase, hepatite, leptospirose etc.

Os catadores contraem diversos tipos de doenças relacionadas ao trabalho: hérnia de disco, doenças reumáticas, problemas do sistema muscular, problemas do sistema articular (SILVA, 2006).

Segundo Santos (2008) os catadores relatam diferentes agravos à saúde como furadas de agulhas e dores musculares em várias partes do corpo relacionadas a movimentos repetitivos e diferentes esforços físicos para realização de seu trabalho diário.

A atividade de catação pelas ruas de Fortaleza-CE envolve diversos riscos, porém apenas $20 \%$ dos entrevistados afirmou adotar algum cuidado na hora de manusear o lixo que encontra na rua, como olhar atentamente o que existe no saco de lixo, rasgar com cuidado os sacos plásticos etc.

Agrava a situação o fato de $92 \%$ dos entrevistados não utilizarem nenhum equipamento de proteção individual. Esse resultado tem estreita relação com dois aspectos: a renda do catador não lhe permite comprar materiais de segurança (luva, máscara etc) e, caso fossem ofertados gratuitamente tais equipamentos, há grande rejeição ao uso, pois alegam que atrapalha a velocidade de trabalho, diminui a sensibilidade das mãos e é desconfortável.

De acordo com Hoefel et al. (2013) os catadores, em sua maioria, já sofreram algum tipo de acidente e a exposição aos riscos aumenta com o fato de não utilizarem equipamentos de proteção individual (EPIs).

Esse cenário naturalmente resulta em cortes e arranhões; narrados por $32 \%$ dos entrevistados. Outro aspecto que merece atenção é que $23 \%$ dos entrevistados já sofreu algum acidente de trânsito enquanto coletava materiais pelas ruas, tanto com ônibus quanto com carros de passeio.

A precariedade dos instrumentos de trabalho e as dificuldades na organização laboral deixam os catadores expostos aos acidentes e atropelamentos, além das agressões físicas e psicológicas, situação de humilhação e elevado desgaste físico (SILVA, 2006). Trata-se de uma atividade desprovida de segurança (BOLFE et al., 2014).

Entre os entrevistados, $92 \%$ se consideram satisfeitos com o trabalho, curiosamente. Alguns consideram uma atividade digna e honesta. Outros gostam da liberdade e da autonomia que a atividade proporciona. Essa liberdade tem sido apontada como principal motivo para não pertencer a uma associação e/ou cooperativa.

A grande maioria (88\%) também percebe a importância do seu trabalho para a limpeza da cidade, reciclagem e preservação ambiental. Resultados semelhantes foram encontrados por Santos (2008), Araújo (2009) e Teixeira, V. (2010).

De acordo com Cruz et al. (2012) os catadores - que são vistos pela sociedade como ignorantes - muitas vezes possuem mais consciência da importância da separação dos resíduos do que muitos cidadãos, e estes trabalhadores se destacam por desempenhar um importante papel para o planeta.

\section{Considerações finais}

Os catadores que trabalham no Centro da cidade de Fortaleza-CE possuem perfil social semelhante ao observado em outras cidades brasileiras, especialmente com relação a desestrutura familiar, baixo nível de escolaridade e renda.

Ao longo dos anos, o trabalho de catação foi insuficiente para melhorar suas condições de vida, por isso os entrevistados preferem que seus filhos estudem e venham a exercer outra atividade.

A carga horária habitualmente trabalhada torna a atividade extenuante, porém a prioridade dos catadores é garantir a subsistência, independente dos riscos, possíveis doenças, condições de higiene e trabalho. 
Diversos tipos de preconceito, agressões psicológicas e condições insalubres de trabalho fazem parte do cotidiano dos catadores entrevistados.

O tipo e a quantidade de material recolhido impactam diretamente na renda dos catadores, mas a subordinação aos donos de depósito tem maior poder de influência sobre essa renda.

Uma característica aparentemente comum entre os catadores é a resiliência, ou seja, a capacidade de enfrentar, aprender, crescer e amadurecer com as adversidades, dificuldades, conflitos da vida, usando recursos internos para uma nova maneira de encarar as situações.

Os catadores entrevistados representam um grupo que precisa ser atendido pela Política Nacional de Saúde do Trabalhador, já que a mesma contempla pessoas e grupos em situação de maior vulnerabilidade, em atividades de maior risco para a saúde e submetidas a formas nocivas de discriminação.

Essa pesquisa permitiu traçar um rápido, mas inédito, perfil social, econômico e do trabalho dos catadores autônomos que trabalham no Centro da cidade de Fortaleza-CE, sendo seus resultados uma contribuição para o re(conhecimento) dessas pessoas e para orientação de políticas públicas.

\section{Referências}

ABREU, E. P de. Condições de trabalho, saúde e hábitos de vida dos catadores de resíduos sólidos da vila Vale do Sul em Aparecida de Goiânia-GO. 2011. 66 f. Dissertação (Mestrado em Ciências Ambientais e Saúde) - Pontifícia Universidade Católica de Goiás, Goiânia, 2011.

ALMEIDA, M. de. F. G de; FIGUEIREDO, P. S.; BARBOSA, J. D. V. Um diagnóstico das condições sócio-econômicas dos catadores de materiais reutilizáveis e recicláveis dos municípios de Pequeno Porte da Bahia. In: ENCONTRO DA ASSOCIAÇÃO NACIONAL DE PÓS-GRADUAÇÃO E PESQUISA EM ADMINISTRAÇÃO. 38., 2014, Rio de Janeiro. Anais...Rio de Janeiro, 2014. p. 1-16.

AQUINO, F. C. et al. Aspectos socioeconômicos de catadores de recicláveis em uma associação em Santo Antônio do Monte-MG. InterfacEHS - Saúde, Meio Ambiente e Sustentabilidade, São Paulo, v. 10, n. 1, p. 157-165, jun. 2015.

ARAÚJO, J. A de. Percepçôes e atitudes diante dos riscos ambientais à saúde de catadores de materiais recicláveis da comunidade de São José do Coque, Recife/PE. 2009. 144 f. Dissertação (Mestrado em Saúde Pública) - Fundação Oswaldo Cruz, Recife, 2009.

ASSOCIAÇÃO BRASILEIRA DE EMPRESAS DE LIMPEZA PÚBLICA E RESÍDUOS ESPECIAIS (ABRELPE). Panorama dos Resíduos Sólidos no Brasil. Brasília, DF: ABRELPE, 2014. Disponível em: <http://www.abrelpe.org.br/ panorama_apresentacao.cfm.>. Acesso em: 2 jan. 2016.

BASTOS, H. M.; ARAÚJO, G. C de. Cidadania no contexto dos catadores autônomos de materiais recicláveis. Rev. Adm. UFSM, Santa Maria, v. 8, p. 60-73, 2015. Ed. especial XVI ENGEMA.

BENVINDO, A. Z. A nomeação no processo de construção do catador como ator econômico e social. $2010.96 \mathrm{f}$.

Dissertação (Mestrado em Ciências Sociais) - Universidade de Brasília, Brasília, 2010.

BOLFE, S. A. et al. O trabalho cotidiano dos catadores no urbano periférico da cidade de Santa Maria, RS: caso do bairro Camobi. Ciência e Natura, Santa Maria, v. 36, p. 573-586, 2014. Ediação especial II.

BORTOLI, M. A. Catadores de materiais recicláveis: a construção de novos sujeitos políticos. Rev. Katál, Florianópolis, v. 12, n. 1, p. 105-114 jan./jun. 2009.

BOSI, A. P. A organização capitalista do trabalho "informal": o caso dos catadores de recicláveis. Revista Brasileira de Ciências Sociais, São Paulo, v. 23, n. 67, p. 101-116, jun. 2008.

BRASIL. Decreto n. 5940, de 25 de outubro de 2006. Institui a separação dos resíduos recicláveis descartados pelos órgãos e entidades da administração pública (...). Diário Oficial da União, Brasília, DF, 26 out. 2006. Disponível em: < http://www.planalto.gov.br/ccivil_03/_Ato2004-2006/2006/Decreto/D5940.htm>. Acesso em: 24 jan. 2016.

. Decreto n. 7405, de 23 de dezembro de 2010. Institui o Programa Pró-Catador, denomina Comitê Interministerial para Inclusão Social e Econômica dos Catadores de Materiais Reutilizáveis e Recicláveis (...). Diário Oficial da União, Brasília, DF, 23 dez. 2010. Disponível em: <http://www.planalto.gov.br/ccivil_03/_Ato2007-2010/2010/ Decreto/D7405.htm >. Acesso em: 24 jan. 2016. 
. Instrução Normativa n. 1, de 19 de janeiro de 2010. Dispõe sobre os critérios de sustentabilidade ambiental na aquisição de bens, contratação de serviços ou obras pela Administração Pública Federal direta, autárquica e fundacional e dá outras providências. Disponível em: $<\mathrm{http}$ ://www.comprasnet.gov.br/legislacao/legislacaoDetalhe. asp?ctdCod=295>. Acesso em: 24 jan. 2016.

. Lei no 12305, de 2 de agosto de 2010. Institui a Política Nacional de Resíduos Sólidos e dá outras providências. Diário Oficial da União, Brasília, DF, 3 ago. 2010. Disponível em: <http://www.planalto.gov.br/ccivil_03/_ato20072010/2010/lei/112305.htm>. Acesso em: 24 jan. 2016.

. Lei no 12309 , de 9 de agosto de 2010. Dispõe sobre as diretrizes para a elaboração a execução da Lei Orçamentária de 2011 e dá outras providências. Diário Oficial da União, Brasília, DF, 10 ago. 2010. Disponível em: <http://www.planalto.gov.br/ccivil_03/_ato2007-2010/2010/lei/112309.htm>. Acesso em: 24 jan. 2016.

. Lei no 8666, de 21 de junho de 1993. Regulamenta o art. 37, inciso XXI, da Constituição Federal, institui normas para licitações e contratos da Administração Pública e dá outras providências. Diário Oficial da União, Brasília, DF, 22 jun. 1993. Disponível em: <http://www.planalto.gov.br/ccivil_03/leis/L8666cons.htm>. Acesso em: 27 fev. 2016.

.Ministério das Cidades. Secretaria Nacional de Saneamento Ambiental. Lixo e Cidadania: guia de ações e programas para a gestão de resíduos sólidos. Brasília, DF, 2005. Disponível em: <http://www2.camara.leg.br/atividadelegislativa/comissoes/comissoes-permanentes/cdu/documentos/publicacoes/lixo-e-cidadania/view>. Acesso em: $12 \mathrm{fev}$. 2016.

. Ministério da Saúde. Portaria ${ }^{\circ} 1823$, de agosto de 2012. Institui a política nacional de saúde do trabalhador e da trabalhadora. Brasília, DF, 2012. Disponível em: <http://bvsms.saude.gov.br/bvs/saudelegis/gm/2012/ prt1823_23_08_2012.html>. Acesso em: 12 fev. 2016.

. Ministério da Saúde. Saúde do Trabalhador. Cadernos de Atenção Básica, n.5. Brasília, DF, 2002.

. Ministério do Meio Ambiente. Plano nacional de resíduos sólidos. Brasília, DF, 2012. Disponível em: <http:// www.mma.gov.br/port/conama/reuniao/dir1529/PNRS_consultaspublica s.pdf >. Acesso em: 12 fev. 2016.

. Ministério do Meio Ambiente. $4^{\circ}$ conferência nacional do meio ambiente. Resíduos sólidos: relatório final. Brasília, DF, 2013. Disponível em: < http://www.promea-rio.com.br/docs/30.Relat\%C3\%B3rio\%20Final\%20-\%20 4\%C2\%AA\%20Conferencia\%20Nacional\%20do\%20Meio\%20Ambiente\%20-\%20CNMA_WEB.pdf >. Acesso em: 12 fev. 2016.

.Ministério do Trabalho. Norma regulamentadora - NR 15: atividades e operações insalubres. 1978. Disponível em: <http://trabalho.gov.br/seguranca-e-saude-no-trabalho/normatizacao/normas-regulamentadoras/normaregulamentadora-n-15-atividades-e-operacoes-insalubres $>$. Acesso em: 12 fev. 2016.

. Plano Nacional sobre Mudança do Clima. Brasília, DF: Comitê Interministerial sobre Mudança do Clima, 2008.

K. N. L. Identidades em construção: conhecendo as narrativas da história de vida dos catadores de materiais recicláveis de Icó-Ceará. 2015. 108 f. Dissertação (Mestrado em Psicologia) - Universidade Federal do Ceará, Fortaleza, 2015.

CARVALHO, M. A. de. Perfil sócio-econômico dos coletores de resíduos sólidos recicláveis no município de Goioerê/PR. 2011. 56 f. Monografia (Especialização em Gestão Pública Municipal) - Universidade Tecnológica Federal do Paraná, Curitiba, 2011.

CASTILHOS JUNIOR, A. B. de. et al. Catadores de materiais recicláveis: análise das condições de trabalho e infraestrutura operacional no Sul, Sudeste e Nordeste do Brasil. Ciências \& Saúde Coletiva, Rio de Janeiro, v. 18, n. 11, p. 3115-3124, nov. 2013.

CATAFORTE. Assim como os resíduos sólidos, os nossos hábitos também devem ser reciclados. Disponível em: <http://goo. gl/1Thrs8>. Acesso em: 23 jan. 2016.

CAVALCANTE, L. P. S.; ALENCAR, L. D. de; BARBOSA, E. M. Conflitos socioambientais que envolvem catadores de materiais recicláveis informais que atuam no bairro Catolé, Campina Grande-PB. In: SEMINÁRIO NACIONAL DE RESÍDUOS SÓLIDOS - DESAFIOS PARA A IMPLANTAÇÃO DA POLÍTICA NACIONAL, 11, 2014, Brasília. Anais... Brasília, DF: ABES, 2014. p. 1-7.

CAVALCANTE, S.; FRANCO, M. F. A. Profissão perigo: percepção de risco à saúde entre os catadores do lixão do Jangurussu. Revista mal-estar e subjetividade, Fortaleza, v. 7, n. 1, p. 211-231, 2007. 
(Re)conhecimento das condições de vida dos catadores autônomos de materiais reutilizáveis e recicláveis do Centro de Fortaleza

CEARÁ. Lei no 12225, de 06 de dezembro de 1993. Diário Oficial do Estado, Fortaleza, 10 dez. 1993.

. Secretaria Municipal de Meio Ambiente e Controle Urbano. Plano municipal de gestão integrada de resíduos sólidos de Fortaleza estado do Ceará: Relatório IV. Fortaleza, 2012. Disponível em: <http://www.progere.ufc.br/wpcontent/uploads/2015/08/Plano-Municipal-de-Gest\%C3\%A3o-Integrada-de-Res\%C3\%ADduos-S\%C3\%B3lidos-deFortaleza.pdf>. Acesso em: 22 fev. 201

COMPROMISSO empresarial para reciclagem-cempre. Disponível em: $<$ http://www.cempre.org.br $>$. Acesso em: 8 jan. 2016.

COUTO, G. A. Aprendizagem social e formação humana no trabalho cooperativo de catadores(as) em São Paulo. 2012. 183 f. Dissertação (Mestrado em Educação) - Universidade de São Paulo, 2012.

CRUZ, C. D. et al. Um panorama dos catadores de materiais recicláveis organizados em cooperativas no município de Erechim/RS. Perspectiva, Erechim. v. 36, n. 135, p. 65-73, set. 2012.

DIAS, A. R. Condições de vida, trajetórias e modos de "estar" e "ser" catador: estudo de trabalhadores que exercem atividade de coleta e venda de materiais recicláveis na cidade de Curitiba (PR). 2002. 99 f. Dissertação (Mestrado em Psicologia) - Universidade de São Paulo, São Paulo, 2002.

DOBRACHINSKI, L.; DOBRACHINSKI, M. M. M. Condições de vida, trabalho e saúde dos catadores de materiais recicláveis do lixão de um município do Oeste da Bahia. Hígia, Barreiras, v. 1, n. 1, p. 18-45, 2016.

FEITOSA. L. de B. Sentidos atribuidos às políticas públicas de inclusão dos catadores pelos atores envolvidos na discussão dos resíduos sólidos. 2011. 152 f. Dissertação (Mestrado em Psicologia) - Universidade Federal do Ceará, Fortaleza, 2011.

FILARDI, F.; SIQUEIRA, E. S.; BINOTTO, E. Os catadores de resíduos e a responsabilidade socioambiental: a percepção sobre seu lugar social. Revista de Gestão Social e Ambiental, São Paulo, v. 5, n. 3, p.17-35, set./dez. 2011.

FROTA, A. J. A. Coleta seletiva na cidade de Fortaleza-CE: desafios e perspectivas de sustentabilidade nas associações de catadores de resíduos sólidos. 2014. 165 f. Dissertação (Mestrado em Administração de Empresas) Universidade de Fortaleza, Fortaleza, 2014.

GALDINO, S. de J.; MALYSZ, S. T. Catadores de materiais recicláveis e coletores do município de Mamborê-PR: agentes fundamentais no processo de gerenciamento dos resíduos sólidos urbanos. In: ENCONTRO DE PRODUÇÃO CIENTÍFICA E TECNOLÓGICA - EPCT. 7., 2012, Paraná, Anais... Paraná: NUPEM, 2012. p. 1-10.

GALON, T. Do lixo à mercadoria, do trabalho ao resgate: estudo do processo de trabalho e suas implicações na saúde dos catadores de materiais recicláveis. 2015. 225 f. Tese (Doutorado em Ciências) - Universidade de São Paulo, Ribeirão Preto, 2015.

GONÇALVES, R. M. de P. A catação de lixo na (de)formação da criança como ser social. 2006. 216 f. Tese (Doutorado em Educação) - Universidade Federal do Ceará, Fortaleza, 2006.

GONÇALVES, C. V. et al. A vida no lixo: um estudo de caso sobre os catadores de materiais recicláveis no município de Ipameri, GO. Holos, Rio Grande do Norte, v. 2, n. 29, p. 238-250, 2013.

GONÇALVES, R. C. M. A voz dos catadores de lixo em sua luta pela sobrevivência. 2005. 134 f. Dissertação (Mestrado em Políticas Públicas e Sociedade) - Universidade Estadual do Ceará, Fortaleza, 2005.

GONÇALVES, R. S. Catadores de materiais recicláveis: trajetórias de vida, trabalho e saúde. 2004. 107 f. Dissertação (Mestrado em Saúde Pública) - Fundação Oswaldo Cruz, Rio de Janeiro, 2004.

GONÇALVES, M. A. O trabalho no lixo. 2006. 310 f. Tese (Doutorado em Geografia) - Universidade Estadual Paulista, Presidente Prudente, 2006.

HOEFEL, M. da G. et al. Acidentes de trabalho e condições de vida de catadores de resíduos sólidos recicláveis no lixão do Distrito Federal. Rev. Bras. Epidemiol., São Paulo, v. 16, n. 3, p. 764-785, set. 2013.

INSTITUTO BRASILEIRO DE ADMINISTRAÇÃO MUNICIPAL - IBAM. Manual de gerenciamento integrado de resíduos sólidos. Rio de Janeiro: Secretaria Especial de Desenvolvimento Urbano da Presidência da República - SEDU/ PR, 200p., 2001.

INSTITUTO BRASILEIRO DE GEOGRAFIA E ESTATÍSTICA. Censo demográfico 2010. Disponível em: <http:// biblioteca.ibge.gov.br/index.php/biblioteca-catalogo?view=detalhes\&id=264529>. Acesso em: 12 mar. 2016. 
INSTITUTO DE PESQUISA E ESTRATÉGIA ECONÔMICA DO CEARÁ. Perfil básico municipal Fortaleza. Fortaleza: IPECE, 2015.

INSTITUTO DE PESQUISA ECONÔMICA APLICADA. Diagnóstico sobre Catadores de Resíduos Sólidos. Relatório de Pesquisa. Brasília, DF: IPEA, 2012. Disponível em: <http://www.ipea.gov.br/portal/index. php?option=com_content\&view=article\&id=15435>. Acesso em: 12 fev. 2016.

. Pesquisa sobre pagamento por serviços ambientais urbanos para gestão de resíduos sólidos. Relatório de Pesquisa. Brasília, DF: IPEA, 2010. Disponível em: <http://www.ipea.gov.br/portal/index.php?option=com _ content\&view=article\&id=8858>. Acesso em: 12 fev. 2016.

Situação Social das Catadoras e dos Catadores de Material Reciclável e Reutilizável. Relatório de Pesquisa. Brasília, DF: IPEA, 2013. Disponível em: <http://www.ipea.gov.br/agencia/images/stories/PDFs/situacao_ social/131219_relatorio_situacaosocial_mat_reciclavel_brasil.pdf $>$. Acesso em: 12 fev. 2016.

IZAIAS, F. M. de C. Na rota do lixo: percursos de vida e trabalho de catadores do complexo de tratamento de resíduos sólidos do Jangurussu. 2010. 151 f. Dissertação (Mestrado em Sociologia) - Universidade Federal do Ceará, Fortaleza, 2010.

KIRCHNER, R. M.; SAIDELLES, A. P. F.; STUMM, E. M. F. Percepções e perfil dos catadores de materiais recicláveis de uma cidade do RS. G\&DR, Taubaté, v. 5, n. 3, p. 221-232, set./dez. 2009.

MAGALHÃES, B. J. Liminaridade e exclusão: os catadores de materiais recicláveis e suas relações com a sociedade brasileira. 2012. 131 f. Dissertação (Mestrado em Antropologia) - Universidade Federal de Minas Gerais, Belo Horizonte, 2012.

MAGERA, M. C. Os empresários do lixo: um paradoxo da realidade. Campinas: Átomo, 2003.

MEDEIROS, L. F. R.; MACEDO, K. B. Catador de material reciclável: uma profissão para além da sobrevivência?. Psicologia \& Sociedade, Florianópolis, v. 18, n. 2, p. 62-71, maio/ago. 2006.

MIURA, P. O.; SAWAIA, B. B. Torna-se catador: sofrimento ético-político e potência em ação. Psicologia \& Sociedade, Florianópolis, v. 25, n. 2, p. 331-341. 2013.

MORAES, C. A de S. Catadores da sobrevivência: a "matéria viva" no cenário do lixo. Vértices, Campos dos Goytacazes, v. 11, n. 1/3, p. 109-124, jan./dez. 2009.

MOREIRA, A. T. X. (Sobre) vivendo do lixo: um estudo das condições de trabalho e de vida dos catadores de lixo do bairro Parque São José. 2013. 82 f. Trabalho de Conclusão de Curso (Graduação em Serviço Social) - Centro de Ensino Superior do Ceará, Faculdade Cearense, Fortaleza, 2013.

OLIVEIRA, M. M. et al. A sobrevivência como foco: cotidiano e perspectivas de futuro dos catadores de materiais recicláveis. Oikos: Revista Brasileira de Economia Doméstica, Viçosa, v. 22, n. 1, p. 6-24, 2011.

OLIVEIRA, D. A. M. de. Percepção de riscos ocupacionais em catadores de materiais recicláveis: estudo em uma cooperativa em Salvador-Bahia. 2011. 175 f. Dissertação (Mestrado em Saúde, Ambiente e Trabalho) - Universidade Federal da Bahia, Salvador, 2011.

OLIVEIRA, A. G. de. et al. Perfil de catadores e catadoras de materiais recicláveis que atuam em Campina Grande PB. In: CONGRESSO BRASILEIRO DE ENGENHARIA SANITÁRIA E AMBIENTAL. 26., 2011, Porto Alegre. Anais... Porto Alegre: ABES, 2011. p. 1-8.

PANTANO FILHO, R.; ROSA, D dos S. Perfil dos cooperados das cooperativas de catadores de resíduos sólidos da cidade de Campinas. In: ZANIN, M.; GUTIERREZ, R. F (Org.). Cooperativas de catadores: reflexões sobre práticas. São Carlos: Claraluz. 2011. p. 357-386.

PEREIRA, A. C. L. Os catadores de materiais recicláveis: trajetórias e travessias. 2010. 135 f. Dissertação (Mestrado em Psicologia) - Faculdade de Ciências e Letras de Assis, Universidade Estadual Paulista, Assis, 2010.

PINHEL, J. F.; ZANIN, M.; DEL MÔNACO, G. Catador de resíduos recicláveis: um perfil profissional em construção. In: ZANIN, M.; GUTIERREZ, R. F (Org.). Cooperativas de catadores: reflexões sobre práticas. São Carlos: Claraluz. 2011. p. 53-101.

PORTO, M. F. de. S. et al. Lixo, trabalho e saúde: um estudo de caso com os catadores em um aterro metropolitano no Rio de Janeiro, Brasil. Cad. Saúde Pública, Rio de Janeiro, v. 20, n. 6, p. 1503-1514, nov./dez. 2004.

RABELO, G. B.; SILVA, A. L. da; CARNEIRO, C. M. B. O perfil social e econômico dos catadores de papel/papelão 
$(\mathrm{Re})$ conhecimento das condições de vida dos catadores autônomos de materiais reutilizáveis e recicláveis do Centro de Fortaleza

do Centro da cidade de Fortaleza (CE) e o processo de inclusão social. In: SEMANA DO MEIO AMBIENTE. 4., 2006, Fortaleza. Anais... Fortaleza, 2006.

RANCURA, S. Aspectos Ecológicos e sociais da coleta informal de resíduos sólidos urbanos do município de São Carlos-SP. 2005. 99 f. Dissertação (Mestrado em Ecologia e Recursos Naturais) - Universidade Federal de São Carlos, São Carlos, 2005.

RIBEIRO, S. Q. A territorialização de catadores em cooperativas de resíduos recicláveis: o caso dos catadores organizados na cooperativa de trabalhadores catadores de material reciclável-COOTACAR/Cascavel/PR. 2009. $117 \mathrm{f}$. Trabalho de Conclusão de Curso (Graduação em Geografia) - Campus de Marechal Cândido Rondon, Universidade Estadual do Oeste do Paraná, Marechal Cândido Rondon, 2009.

RIBEIRO, I. M.; NARDI, H. C.; MACHADO, P. S. Catadoras(es) de materiais recicláveis e as possíveis articulações entre trabalho precário e relações de gênero. Cadernos de Psicologia Social do Trabalho, São Paulo, v. 15, n. 2, p. 243 254, 2012.

RIOS, C. M. Lixo e cidadania: um estudo sobre catadores de recicláveis em Divinópolis-MG. 2008. 81 f. Dissertação (Mestrado em Educação, Cultura e Organizações Sociais) - Universidade do Estado de Minas Gerais, Divinópolis, 2008 .

ROLIM, R. S.; TEIXEIRA, K. M. D.; FERNANDES, R de A. U. "Uns valorizam, outros discriminam”: família e sociedade na percepção dos catadores de materiais recicláveis. Oikos: Revista Brasileira de Economia Doméstica, Viçosa, v. 26, n. 1, p. 205-224, 2015.

SANTOS, I. J. Determinantes dos rendimentos de catadores de materiais recicláveis no Brasil: uma abordagem a partir dos microdados da amostra do censo IBGE 2010. Revista Pegada, São Paulo, v. 14, n. 1, p. 298-329, jul. 2013.

SANTOS FILHO, I. C. M.; ROCHA, M. A.; LIMA FILHO, M. A. O lixo que gera renda: catadores de materiais recicláveis do aterro controlado de Teresina-PI. In: CONGRESSO NORTE NORDESTE DE PESQUISA E INOVAÇÃO - CONNEPI. 7., 2012, Palmas, Anais... Palmas, 2012.

SANTOS, G. O.; RIGOTTO, R. M. Possíveis impactos sobre o ambiente e a saúde humana decorrentes dos lixões inativos de Fortaleza (CE). Revista Saúde e Ambiente. Rio de Janeiro, v. 9, n. 2, p. 55-62, dez. 2008.

SANTOS, G. O. Resíduos sólidos domiciliares, ambiente e saúde: (Inter)relações a partir da visão dos trabalhadores do sistema de gerenciamento de resíduos sólidos de Fortaleza/CE. 2008. 164 f. Dissertação (Mestrado em Saúde Pública) Universidade Federal do Ceará, Fortaleza, 2008.

SEVERO, R. G. Catadores de materiais recicláveis da cidade de Pelotas: situações de trabalho. 2008. 128 f. Dissertação (Mestrado em Ciências Sociais) -Universidade Federal de Pelotas, Pelotas, 2008.

SILVA, A. P. P. da; SANTOS, G. O. Lixo e trabalho: quem são os catadores afinal?. In: ENCONTRO INTERNACIONAL TRABALHO E PERSPECTIVAS DE FORMAÇÃO DOS TRABALHADORES. 4., 2015, Fortaleza, Anais... Fortaleza, 2015.

SILVA, M. C. Trabalho e saúde dos catadores de materiais recicláveis em uma cidade do sul do Brasil. $2006.229 \mathrm{f}$. Tese (Doutorado em Ciências) - Faculdade de Medicina, Universidade Federal de Pelotas, 2006.

SILVA, M. do S. F.; JOIA, P. R. Situação sócio-econômica dos catadores de materiais recicláveis na cidade de Aquidauana/MS. Revista Terra Plural, Ponta Grossa, v. 2, n. 1, p. 25-39, jan./jun. 2008.

SILVA. R. R. S. da.; LUBARINO, P. C. da C.; SOUZA, G. M. M de. Principais dificuldades dos catadores de lixo de Petrolina, PE, e Juazeiro, BA. Rev. Acad., Ciênc. Agrár. Ambient., Curitiba, v. 8, n. 2, p. 235-248, abr./jun. 2010.

SOARES, A. P. Perfil socioeconômico dos catadores de materiais recicláveis do lixão de São José da Varginha/ Minas Gerais - e principais mecanismos para implementar políticas públicas de inclusão social. In: CONGRESSO BRASILEIRO DE GESTÃO AMBIENTAL, 20., 2014, Belo Horizonte. Anais... Belo Horizonte: IBEAS, 2014. p. 1-6.

SOUSA, F. K de. Perfil social dos catadores de resíduos sólidos recicláveis gerados na UFPR. 2009. 32 f. Trbalho de Conclusão de Curso (Graduação em Ciências Biológicas) - Universidade Federal do Paraná, Curitiba, 2009.

TAVARES, I. A. F. Do lixo à reciclagem: uma visão sobre o trabalho dos catadores no município de Divinópolis. 2009. 86 f. Dissertação (Mestrado em Educação, Cultura e Organizações Sociais) - Universidade do Estado de Minas Gerais, Divinópolis, 2009. 
TEIXEIRA, V. F. O perfil socioambiental dos catadores de lixo da Barra Mansa: associados e não associados à cooperativa de lixo. 2010. 46 f. Monografia (Especialização em Democracia Participativa República e Movimentos Sociais) - Universidade Federal de Minas Gerais, Barra Mansa, 2010.

TEIXEIRA, M. M. Realidade revelada: os catadores informais de materiais recicláveis no contexto da Universidade de Brasília. 2010. 190 f. Dissertação (Mestrado em Desenvolvimento Sustentável) - Centro de Desenvolvimento Sustentável, Universidade de Brasília, Brasília, DF, 2010.

TENÓRIO, M. C. C. Análise de desempenho de cooperativas de separadores de recicláveis na gestão ambiental em Maringá-PR. 2007. 189 f. Dissertação (Mestrado em Geografia) - Universidade Estadual de Maringá, Maringá, 2007.

TROMBETA, L. R. O trabalho de catadores de materiais recicláveis: da precarização à organização do trabalho. Revista Pegada, São Paulo, v. 13, n. 1, p. 55-75, jun. 2012.

VIEIRA, M. E. de A. Percepção de autonomia entre os catadores de materiais recicláveis de associações e organizações privadas de Fortaleza-CE. 2011. 109 f. Dissertação (Mestrado em Psicologia) - Universidade de Fortaleza, Fortaleza, 2011.

WALDMAN, M. et al. Trabalho e saúde: um estudo sobre os catadores de recicláveis em Poços de Caldas-MG. Revista IPH. São Paulo, n. 11. p. 44-64, dez. 2014.

Sobre os autores

\section{Ana Patrícia Pereira da Silva}

Graduada em Biologia pela Universidade Estadual do Ceará (UECE) e Mestranda em Tecnologia e Gestão Ambiental pelo Instituto Federal de Educação, Ciência e Tecnologia do Ceará - IFCE (Campus Fortaleza).

\section{Gemmelle Oliveira Santos}

Dr. em Saneamento Ambiental pela Universidade Federal do Ceará (UFC) e Professor do Mestrado em Tecnologia e Gestão Ambiental do IFCE (Campus Fortaleza). 